\title{
Aspects of political theology in the spiritual autobiography of Mother Teresa of Calcutta
}

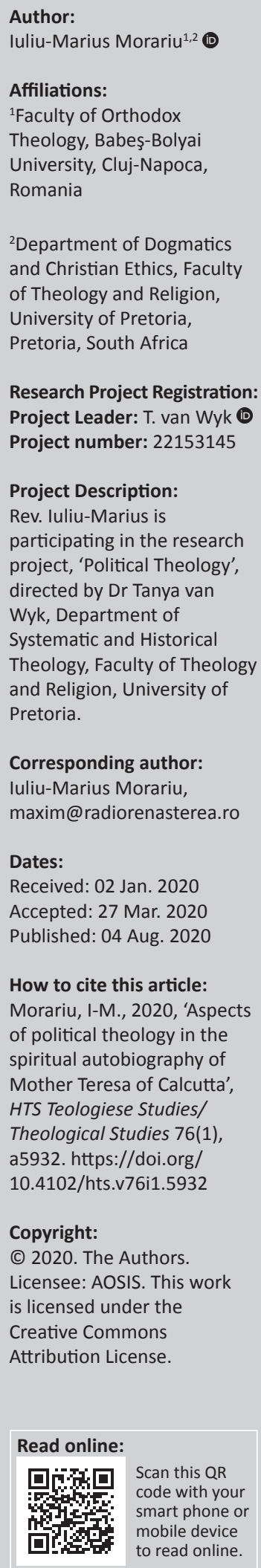

Author:

\section{Affiliations:}

sity, Cluj-Napoca,

${ }^{2}$ Department of Dogmatics and Christian Ethics, Faculty Pretoria, South Africa

Research Project Registration: Project Leader: T. van Wyk

Project Description:

Rev. Iuliu-Marius is participating in the research cted by Dr Tanya van Systematic and Historical Theology, Faculty of Theology and Religion, University of

Corresponding author: Iuliu-Marius Morariu, maxim@radiorenasterea.ro

Dates:

Accepted: $27 \mathrm{Mar}$

Published: 04 Aug. 2020

How to cite this article: of political theology in the spiritual autobiography of Mother Teresa of Calcutta, a5932. https://doi.org/ 10.4102/hts.v76i1.5932

Licensee: AOSIS. This wor

is licensed under the

Creative Common

Attribution License.

to read online.
By resorting to the spiritual autobiography of Mother Teresa of Calcutta, an important religious and cultural personality of the 20th century, the author tries to emphasise the aspects of political theology that defined her way of acting and thinking and to show how she understood the relationship between religion and politics. Topics like poverty, love, giving, peace, sacrifice or responsibility are presented as keywords in the understanding of a complex vision with interdisciplinary relevance, while the two levels of poverty, namely the material one, often accompanied by physical pain, maladies and other types of suffering, and the spiritual one, that is not necessarily related to the lack of basic material needs and can be found even in developed countries like the United States of America or Japan, are seen through the lenses of political theology. The author shows that, by finding practical bridges between spirituality and politics and by using as sources of inspiration not only Christian thinkers, but also thinkers from other religions, like Ghandi, the Albanese militant accomplished her vocation and also offered important and perennial principles which can help in the understanding of the contemporary world and in finding solutions to some of its crises. Although her message is a sort of combination between theology and social life, the political accents, sometimes theoretical, at other times practical, are important and can be used today for the development of a sustainable discourse for both the theological and the political sphere.

Contribution: The article brings into attention a spiritual autobiography that was not valorised properly by the contemporary research and in the same time offers an inter-disciplinary approach with ecumenical value.

Keywords: political theology; social theology; ecumenism; Teresa of Calcutta; pours.

\section{Introduction}

Among the personalities that have changed the history of the 20th century, Teresa of Calcutta is clearly outstanding. Without having preached a systematic doctrine and written on a specific topic concerning the religious or philosophical space, she remains one of the deepest personalities of the world and her message is still analysed and debated by contemporary researchers (Chungath 2009; Feldman 1998; Morariu 2019a:307-312, 2019b:231-239; Silveyra 2019:20-21). Being a religious person with a pragmatic vision, Teresa of Calcutta had a message which was rather social than theological or political.

Still, her teachings and actions were guided by God and by her love for the poor. Therefore, as one of her contemporary biographers underlined: '[I]f mother Teresa's entire life and message were to be summarized and described in only two words, without question those words would be God and Love.' (Kolodiejchuk 2010a:11).

However, despite the fact that her life's purpose was never the publication of a written work, Mother Teresa has left us several books, most of them with a deep theological content, also defined by a huge diversity of styles (because she combines haiku poems in the diary, with short meditations or essays on different topics). Aware of this fact, we will try to emphasise the aspects of political theology which can be found in her spiritual autobiography and to speak about their present validity. But before doing that, there is a short methodological observation which must be made. Compared with other spiritual autobiographies, like that of Dag Hammarskjöld (Erling 2010; Hammarskjöld 1972; Morariu 2016), Saint Silouane from Mounth Athos (Saint Silouane the Athonite 1976, 1994) or Teresa of Avila (Avila 1995), which are compact works published in some cases in several editions and languages, and accompanied by comments on their exegesis or biographers, in the case of Mother Teresa there is not only one work that can be considered her spiritual autobiography.

Therefore, her book published in 1990 (Teresa of Calcutta 1990), where she tries to present the work of 'Missionaries of Charity' rather than to speak about her life and her mystical experiences, contains 
aspects related to her spiritual experience. Then, Come, be my light (Madre Teresa di Calcutta 2007), edited by Brian Kolodiejchuk, can also be considered a work that contains relevant aspects of her spiritual autobiography. However, it must be mentioned that, three years after the release of the book, the same editor offered a new book, which he considered an appendix or a continuation of the first one (Kolodiejchuk 2010b:9). This is also important for our investigation due to the consistent pages of the diary or notes, which will help us to have a better understanding of the way in which the Albanese writer understood the world, of her mission or of her view on political theology and its outcomes. Aware of this aspect, we will resort to all of them and, whenever necessary, we will also try to compare their content in order to offer to the reader a landscape of her way of thinking.

\section{Aspects of political theology in the spiritual autobiography of Mother Teresa of Calcutta}

\section{Teresa's understanding of political theology}

Before speaking about the aspects of political theology that can be found in the notes of Teresa of Calcutta, we must mention the fact that for her, political theology was not a main topic or a daily concern. If one imagines her as a Carl Schmitt (Schmitt 1985; Stoeckl, Gabriel \& Papanikolau 2017) of India, who meditated on the dynamics of the relationships between the political and the theological space throughout time, or who offered suggestions regarding the potential cooperation between the state and the Church and potential common political attitudes, then he or she will most probably be disappointed.

Differences can also be found in the comparison with other spiritual autobiographies, like the one of the Lutheran Swedish thinker Dag Hammarskjöld (Morariu 2018:3), who was a diplomat.

Why? The answer is simple. Being a pragmatic woman, who had a clear and practical purpose, Teresa was not interested in understanding the theoretical mechanisms of political theology, but rather in using them as tools that helped her in the accomplishment of her tasks and calling. Therefore, it can be said that she had an empirical understanding of political theology rather than a practical one. This explains why most of her references to political theology come from the area of social theology instead of the political area and why her understanding of the elements of political theology comes, most of the times, from the social area.

Thus, an investigation like the present must from the very beginning, assume the fact that it is an attempt to understand a special way of thinking, in which the relationship between theology and politics is seen through the social lenses.

\section{Aspects of political theology in the spiritual autobiography of Mother Teresa of Calcutta}

Mother Teresa often provides keys for understanding and interpreting the social and political realities through her way of living and perceiving the world. Her main purpose is not that of offering a theoretical basis for the understanding of political life or of the religious aspects that can be used in politics, but by presenting principles and of highlighting what is necessary. As such, in a consumer society, in which the emphasis is on production, money and business, she sticks to the relevance of 'offering' as an act of fulfilment of the human being. A note from her diary is relevant for this aspect:

Yesterday, a wealthy man from Holland came and said, 'I have lots of money.' He was shocked to hear me say, 'I do not need your money.' He just looked at me. He expected me to become all excited and to start listing the places where we need money for this and that. Then he said, ' $[b]$ ut I want to do something.' Then of course I gave him the address of our sisters in Tanzania, where the people are starving [...]. When I gave him that address, you could see the joy in his face. First there had been surprise and then joy. We need to show the people that it is not their money that is important, but the 'giving'. (Teresa of Calcutta 2010:55)

According to Mother Teresa it is very important to make people understand that the act of offering is that which makes someone feel a real human being, that which makes him or her more human. Therefore, although donations are important for the development of humanitarian activities, the really important aspect is the charity that accompanies them. This is not only a moral principle, but it can and should be used in the economic area as well and it could also be functional in the political one, where it can change mental attitudes and even constitute the basis for a new system built on mutual help and reciprocity.

Considering herself a pencil in God's hands (Slavicek 2007:5), ${ }^{1}$ Teresa understands the material dimension of life only in relation to Providence. Therefore, when she has a purpose, she trusts it to the Lord. Thus, her life is based on a strong relationship and communication with God, whose values are not only ecumenical, but also social. In one of her notes, she speaks about this aspect, relating it to the financial issue, which can constitute a burden for a complex activity like the one developed by the 'Missionaries of charity', the congregation founded by her. There, she underlines the fact that:

Money is not an issue that we are concerned with. God is the one who gives it. We do His work. And he offers us the means for accomplishment. If He does not offer us the mean, then He does not want that work to be done. In such a situation, why should we worry? (Morariu 2019b:235; Teresa di Calcutta 1990:64)

In the present political and economic systems, such a way of thinking would surely be considered impossible and foolish. Still, one aspect of Mother Teresa's vision on the material aspects, namely the consultation with God, could definitely be implemented. If politicians tried more often to think about how God sees their decisions, many political decisions would clearly look different. Even if they did not think strictly about God, but about the citizens and their priorities, this would certainly represent a great step forward. And, indirectly, Teresa of Calcutta suggests this through the message of her

1.As the editor of her works underlines: 'She considered herself only a pencil in God's hands and she was convinced that God used her and her "nothing" to show his Majesty' (Kolodiejchuk 2007b:9). 
entire life and through some of the notes from her spiritual autobiography (Morariu 2019b:237).

Mother Teresa's good understanding of social realities helped her to also have a deeper sense and understanding of the local political landscapes. Having founded a congregation which in a short space of time spread to a global level and had branches all around the world, she even convinced the people she interacted with to change their way of seeing and understanding the political and religious realities, based on the principles of life that she applied. It was not only the lack of basic material needs that represented the foundation for her understanding of poverty; there were also other forms of this disease that she was concerned with. And when she had the occasion, she spoke about that. The fact that she made servitude a visible manifestation of charity transformed Teresa from a religious person into a very famous one, perceived, especially during the first decades of her work, as a messenger of a strong social message. Still, the deeper understanding of the realities and of the complex structure of a human being would prove that she was not only a provider of medical care or of nursing to the poor, but also a spiritual and, sometimes, a political counsellor (which shines through the constant invitations she received from political representatives all around the world and through her dialogues and through certain situations also mentioned in her notes). Among many other testimonies, a short note from her diary illustrates this aspect in a very interesting way:

When in 1971 we opened our first home in the South Bronx, in the United States, a local priest told me jokingly: 'But how, with all the needs that are in India, how did it come to your mind to come here?' I answered: 'We came here just to serve.' 'But how do you think you'll be able to serve?' he asked again. I told him: 'Maybe we can create a bridge between those who are rich and those who lack everything'. (Teresa di Calcutta 1990:67).

\section{Culture of gratitude}

Understanding the potential development of the relationships between rich and poor people as an exchange represents not only a prophetical aspect of Mother Teresa's teaching, but also a potential strategy which, if put into practice by the competent political organs, could constitute a real solution to social and economic inequities.

Likewise, the culture of gratitude constitutes one of the pillars of her thought. ${ }^{2}$ Teresa is aware of the fact that everything is received from God as a consequence of his love for man and knows that, for this reason, the entire humanity must develop a culture of gratitude. On various occasions, when she met political people all around the world, she approached this topic (Teresa di Calcutta 1990:81). Moreover, she understood the fact that gratitude as a testimony of love must also be practised by people in order to achieve the joy that comes as

2.On this topic and on its relationship with human dignity, she wrote the following in her diary: No one spoils us as much as God. There is a great talk going on all over the world that Mother Teresa is spoiling the people by giving them things for free. Once, at a seminar held in Bangalore, one nun stood up and said to me, in the name of the whole group: 'Mother Teresa, you are spoiling the poor people by giving them things for free. They are losing their human dignity. You should take at least ten nay paisa (less than a few U.S. pennies, o. n.) for what you give them, then they would feel their human dignity more.' When everyone was quiet, I said calmly, ' $[n]$ o one is spoiling as much as God Himself. See the wonderful gifts He has given us for free. Al of you here have no glasses, yet you all can see. Say, if God were to take money fo your sight, what would happen?' (Teresa of Calcutta 2010:31). a gift for the accomplishment of such a complex task. This aspect is mentioned by Teresa in the following note:

A young Hindu couple came to our house and they gave me lots of money and I asked them, 'Where did you get so much money?' And they said, "Two days ago we got married, but before marriage we decided we would not buy wedding clothes, we would not have a wedding feast, we would give you the money.' And I looked at them and I said, 'But how, in our Hindu families that is not done, why did you do this?' And I can never forget the answer they gave me, 'Mother, we loved each other so much that we wanted to share the joy of loving with the people you serve.' (Teresa of Calcutta 2010:54)

\section{'Real love for the poor'}

In her opinion, real love means spreading joy all around the world. Therefore, she tried as much as possible to accomplish this task and to avoid the situations and activities that could bring about the disappearance of this joy. One of them is total distancing from political regimes and activities. She mentions this aspect in her notes ${ }^{3}$ and, in certain situations, her wording is quite clear in this respect: 'We don't want to get involved in politics. The only thing we want is to do our work for Christ' (Teresa di Calcutta 1990:80).

This attitude may look contradictory to a reader who, just a few lines above, read about the way in which she understood certain political realities and accomplished her vocation based on the teachings of Christ. Still, it is not. Why? Because political neutrality is understood by Teresa not as the absence of action, but as a way of keeping aloof from the potential troubles created by possible criticisms to certain regimes.

Instead of criticising, she corrects the errors of a regime and cures the illness created by a bad government.

Starting from the fact that Christian principles have a universal validity, she would preach and teach them in every corner of the world where such a possibility arose. This explains why she would meet even controversial people like Fidel Castro (Teresa di Calcutta 1990:81) in an attempt to understand and prevent 'the clash of civilisations' (Huntington 1993:22). Nonetheless, her approach regarding certain aspects of communism were not very friendly. Although she did not criticise the regime as a matter of fact, she did insist (Kolodiejchuk 2010a:14), like other authors, and stated in documents, theimportance of the person in the accomplishment of tasks such as the social ones:

When someone states, as I once heard the president of the government of the state of East Bengal say, that: ' $[I]$ n a communist country the assistance of those in need must be the care of the state and not of the individual', I respond the same way I did in that circumstance: 'I do not agree with the President when he states that the assistance of the poor and the needy is the exclusive responsibility of the state. It is the responsibility of each and every one of us. In situations of need, every person must feel the call to help his brothers and sisters'. (Teresa di Calcutta 1990:81; cf. Morariu 2019b:234)

3.One example can be found: "We opened a house in the Philippines. On our arrival, we found three houses built: one for the children, one for the dying and another as a residence for the sisters. Two hundred workers were involved. In fifteen days a residence for the sisters. Two hundred workers were involved. In fifteen days
everything was ready. Shortly before the opening of the house, nine young people had already asked to join the congregation. In the country, certain priests and religious people are in prison for their opposition to the government (of Ferdinando Marcos). We do not want to criticise those who govern. We stay away from any political activity' (Teresa di Calcutta 1990:79). 
Conceptions like this one, doubled by practical actions, determined the Nobel committee to grant her one of the most important distinctions in the world in 1979 (Mother Teresa 1979a). Her attempt to accomplish this task, which is a consequence of God's calling, was similar to that of another mystical person, namely Silouane from Athos (Saharov 1973:14), whose aim was that of making her to Christ, ${ }^{4}$ and, as we have tried to demonstrate, was accomplished by means of practical actions morally and socially important. Some of them, such as the actions meant to eradicate the Ethiopian hunger (Teresa di Calcutta 1990:81), were also linked to the political field. Defining her work, Teresa saw this aspect as a way of helping the poor to gain back their strength in order to be reintegrated (Teresa di Calcutta 1990:88). Mother Teresa's attitude towards material things and towards the Other explains her success in the realisation of a real global work which started from almost nothing, as one contemporary theologian (Chungath 2009) underlines:

Towards the end of her life, prestige and international reputation opened all doors for her, but we must remember that she began her work with only five rupees. From a vagabond she was transformed into an entrepreneur of charity. Millions of dollars passed through her hands, but she did not allow anyone to collect funds in her name. (p. 28)

\section{Commitment to peace}

Another important aspect that surely defined her concept of understanding a potential cooperation in the area of political theology, is her commitment to peace (Slavicek 2007:6). In fact, it was this attitude that brought her the Nobel prize (in her speech, the term 'peace' was be used for 19 times (Mother Teresa 1979b). She was influenced by other important thinkers in India who, also militated for peace. One of them was Gandhi. Although she never met him, she had a profound respect for his ideas and work, which became visible in some of her actions, according to a contemporary researcher:

Mother Teresa's lifelong devotion to nonviolence and serving the poor may also have been shaped by the great Indian hero Mohandas K. Gandhi. Born into a devout Hindu family in western India in 1869, Gandhi became one of the most revered political and spiritual leaders of modern times. He used community meetings and boycotts, marches, letters, fasting, and prayer to develop a system of nonviolent resistance that was to play a central role in ending British rule in India after World War II. Mother Teresa never had the opportunity to meet Gandhi, who was assassinated in January 1948. She was well aware of Gandhi's philosophy and career and deeply respected him for his nonviolent principles and compassion for society's forgotten, including lepers. A decade after Gandhi's death, she named her groundbreaking centre for lepers in Titlagarh, India, Gandhi Prem Niwas ('Gandhi Center for Love'), in his honor. (Slavicek 2007:54-55)

As for Gandhi, so for Mother Teresa, peace was also related to a specific state of the soul. Having faced poverty for many years and having tried to cure the ill or to ease their suffering, she did not remain only at the material stage in understanding

4. As she testified: "In 1948, after twenty years of uninterrupted residence in India, opted for a closer contact with the poor and the poorest of the poor. For me, it was apted for a closer contact with the poor and the poorest of the poor. For me, it was (Kolodiejchuk 2007a:22, 2007b:18; Teresa di Calcutta 1990:24). this matter. A small note presented as a dialogue reveals her deep understanding of this issue:

Sometimes, the journalists asked me: 'Since there is so much poverty in India, why did you think, Mother Teresa, to send your sisters to less needy countries?' For this question I always have an answer on my lips, which is the following: The poverty of the West is much worse than the material poverty of India. For this reason, I ask you, should we limit our work of apostolate only to one country, when others call us?

I repeat: there are two types of poverty. In India there are people dying of hunger. Here, even a handful of rice is precious. In Western countries, there is no material poverty in the sense we give to this expression. You don't see anyone starving in these countries. No one gets to experience a hunger as intense as the one because of which many go crazy in India. But in the West there is another kind of poverty: a spiritual poverty. This is much worse. Man does not believe in God, he does not pray [...]. In the West there is the poverty of the people who are not satisfied with what they have, who do not know how to suffer; they are left in despair. This poverty of the heart is often much more difficult to save and treat. (Teresa di Calcutta 1990:108-109)

By suggesting the relationship between spirituality and politics (Valadier 2011:17) as a potential form of cohabitation and improvement of the latter, she offers a potential valid model for political reinforcement and recovered credibility in the Christian sphere. Moreover, in order to prove the validity of this moment, she cooperated with the Indian state authority for social purposes. ${ }^{5}$ The personal crises, sometimes with political accents as well, ${ }^{6}$ did not stop her from fulfilling her vocation and from accomplishing the calling to serve others and to help the poor (Scott 2005:54). Peace represents the landmark of all her speeches, together with topics like 'love' and 'giving', whether she gave talks to civil associations, politicians, Church organisations or scholars.

\section{Global theology and work}

Another important element which shows influences of political theology, is definitely the global composition and growth of her congregation. In just a few years, 'the Missionaries of Charity', first regarded with suspicion by bishops, by social organisations and by other institutions, managed to spread all around the world. In 1990, their founder and coordinator wrote the following on this subject:

Most of our sisters come from India (in fact, our congregation is of Indian origin). But in Rome we have a novitiate with novices from seventeen different nationalities in Europe and America. We also have a novitiate in Australia. Recently, we opened

5. For as one contemporary biographer underlines: 'Working in conjunction with the Indian government, the United Nations, Catholic Relief Services, and a lot of other international organizations, Mother Teresa and her Missionaries of Charity did their best to address the needs of the impoverished and often diseased refugees, particularly the tens of thousands of displaced children. Immediately after the war's end, Mother Teresa also took a team of her Sisters into the new nation of Bangladesh, where they established centres in those areas that were hardest hit by the violence' (Slavicek 2007:61)

6.Such as the one emphasised by the researcher Slavicek (2007): 'In the wake of the Bangladesh crisis, Mother Teresa experienced a bitter personal disappointment. For years, she had been trying to gain permission from Albania's totalitarian government to visit her mother and sister, who had moved from Skopje to Tirana during the early to visit her mother and sister, who had moved from Skopje to Tirana during the early
1930 s to be near Lazar Bojaxhiu. When Benito Mussolini's troops occupied Albania 1930 s to be near Lazar Bojaxhiu. When Benito Mussolini's troops occupied Albania
in 1939, though, Bojaxhiu had joined the fascist dictator's army and ended up in 1939, though, Bojaxhiu had joined the fascist dictator's army and ended up
spending World War II in Italy. At the end of the war, Albania fell under Communist rule, and anyone who had cooperated with the Italian occupiers was branded a rule, and anyone who had cooperated with the Italian occupiers was branded a
traitor. Barred from ever returning home, Bojaxhiu decided to settle permanently in Italy, where he soon married and started a family' (pp. 61-63). 
another one in Africa, due to the fact that we also have a large number of vocations in that continent. And others, in the Philippines, in Poland [...]. (Teresa di Calcutta 1990:42)

Of course, this was not a political strategy based on a certain algorithm, which aimed at influencing the disposal of the houses of help, but still, her ability of being persuasive in in terms of relevant political factors helped her succeed in the accomplishment of a very complex task. The voice of the Lord and his wishes, communicated to Teresa, were transformed, little by little, into practical actions, with huge importance for the social, religious and political space.

\section{Conclusion}

As we have tried to show, although she never understood political theology as a complex and structured system and politics was never a priority for her way of acting in the eradication of poverty, Teresa of Calcutta offers interesting elements in her spiritual autobiography, which are relevant for this topic. Her understanding of the relationship between love, charity, peace, giving or the two dimensions of poverty are important not only for the religious space - where she was active, but also for the political one. If fructified in a responsible way by contemporary politicians, it could clearly contribute to the creation of a new political discourse that would not only succeed in solving crises like the one generated by poverty and eradicate spiritual, social and civic problems, but it would also help the political field to regain its credibility for the citizens and, surely, it would increase the level of social implication and the people's interest in the political arena. Therefore her ideas must certainly be rediscovered and valorised in this area as well, where they can doubtlessly constitute a valuable calling to a recovery of Christian ethical principles as the basis for healthy political decisions, while her life and some of her actions represent examples of a deep understanding not only of the religious vocation, but also of social and political realities, in a holistic context.

\section{Acknowledgements Competing interests}

The author has declared that no competing interest exists.

\section{Author's contributions}

I declare that I am the sole author of this research article.

\section{Ethical consideration}

This article followed all ethical standards for a research without direct contact with human or animal subjects.

\section{Funding information}

This research received no specific grant from any funding agency in public, commercial or not-for-profit sectors.

\section{Data availability statement}

Data sharing is not applicable to this article as no new data were created or analysed in this study.

\section{Disclaimer}

The views and opinions expressed in this article are those of the authors and to not necessarily reflect the official policy or position of any affiliated agency of authors.

\section{References}

Chungath, P., 2009, Price of a precious pearl. Religious poverty lived and taught by blessed Mother Teresa of Calcutta, ISPCK Press, Delhi.

Erling, B., 2010, A reader's guide to Dag Hammarskjöld's Waymarks, Dag Hammarsjkold Foundation, St. Peter, MN.

Feldman, C., 1998, Mother Teresa: Love stays, Crossroad Publishing, New York, NY.

Hammarskjöld, D., 1972, Markings, Faber and Faber, London.

Huntington, S., 1993, 'The clash of civilizations', Foreign Afffairs 72(3), 22-50. https:// doi.org/10.2307/20045621

Kolodiejchuk, B., 2007a, 'Introduzione [Introduction]', in Madre Teresa (ed.), Sii la Mia luce [Be my light], pp. 13-24, M. C. Rizzoli Press, Milano.

Kolodiejchuk, B., 2007b, 'Prefazione [Preface]', in Madre Teresa (ed.), Sii la Mia luce [Be my light], pp. 9-10, M. C. Rizzoli Press, Milano.

Kolodiejchuk, B., 2010a, 'Introduction', in Mother Teresa (ed.), Where there is Love, there is God, pp. 11-17, Gale Cenage Learning, Detroit, MI.

Kolodiejchuk, B., 2010b, 'Preface', in Mother Teresa (ed.), Where there is Love, there is God, pp. 9-10, Gale Cenage Learning, Detroit, MI.

Madre Teresa di Calcutta, 2007, Sii la Mia luce [Be my light], B. Kolodiejchuk (ed.), M.C. Rizzoli Press, Milano.

Morariu, I.-M., 2016, Autobiografia spirituală a lui Dag Hammarskjöld - o abordare teologică [Dag Hammarskjold's spiritual autobiography - A theological approach], Argonaut Press, Cluj-Napoca.

Morariu, I.-M., 2018, 'Aspects of political theology in the spiritual autobiography of Dag Hammarskjöld', HTS Teologiese Studies / Theological Studies 74(4), a4857, 1-5. https://doi.org/10.4102/hts.v74i4.4857

Morariu, I.-M., 2019a, 'Educational aspects in the spiritual autobiography of Mother Teresa of Calcutta', Astra Salvensis 7(2), 307-312.

Morariu, I.-M., 2019b, 'Saint Faustina Kowalska and Saint Teresa of Calcutta - two authors of spiritual autobiographies from the Catholic space of the 20th century', Astra Salvensis 7(1), 231-239.

Mother Teresa, 1979a, 'Facts', viewed 12 December 2019, from https://www. nobelprize.org/prizes/peace/1979/teresa/facts

Mother Teresa 1979b, 'Nobel lecture', viewed 12 December 2019, form https://icln. at/wp-content/uploads/2018/02/Mother-Teresa-Nobel-peace-prize-speech. pdf

Saint Silouane the Athonite, 1976, Ecrits spirituels - extraits, Abbaye de Bellefontainte, Begrolles en Mauges.

Saint Silouane the Athonite, 1994, Între iadul deznădejdii şi iadul smereniei - Însemnăr duhovnicești [Between the hell of desperation and the hell of humility - Spiritual notes], Deisis Press, Alba-lulia.

Saharov, S., 1973, Starets Silouane. Moine du Mont Athos, Editions Presence, Paris.

Schmitt, C., 1985, Political theology: Four chapters on the concept of Sovereignty, MIT Press, Cambridge.

Scott, D., 2005, A revolution of love: The meaning of Mother Teresa, Loyola Press, Chicago, IL.

Silveyra, J.M., 2019, 'Lo spirito di Madre Teresa mi ha aiutato nella sofferenza', Asia News 23(2), 20-21.

Slavicek, L.C., 2007, Mother Teresa: Caring for the world's poor, Chelsea House Books, New York, NY.

Stoeckl, K., Gabriel, I. \& Papanikolau, A. (eds.), 2017, Political theologies in Orthodox Christianity. Common challenges - Divergent positions, T\&T Clark and Bloomberg, Edinburgh.

Teresa of Avila, 1995, Castelul interior [The interior castle], Ars Longa Press, lassy.

Teresa di Calcutta, 1990, La mia vita [My life], Rusconi Press, Milano.

Teresa of Calcutta, 2010, Where there is Love, there is God, B. Kolodiejchuk (ed.), Gale Cenage Learning, Detroit, MI.

Valadier, P., 2011, Lo spirituale e la politica [The spiritual and the politics], Lindau Press, Torino. 